\title{
THE SIGNIFICANCE OF INSTITUTIONS'POTENTIAL TO INCREASE YOUTH CIVIC PARTICIPATION - CASE STUDY OF THE SOUTH BALTIC YOUTH CORE CROUPS NETWORK PROJECT
}

\author{
IZABELA BORUCIŃSKA ${ }^{1}$ \\ Gdańsk University of Technology (Poland)
}

\begin{abstract}
Young people are a very important group of modern societies, they will replace the currently ruling generation and will shape our common future. Due to that, young people have become the relevant target of national and international policy and science researches. Youth civic participation is a key aspect of the development of a society and should be shaped by effective youth policy at national and international level. This paper is an attempt of determining the capacity of public institutions and non-government organizations to develop youth civic participation in the context of the European Union youth policy. It reveals the importance of various elements of the potential of institutions' environment in increasing civic participation of young people on the example of the South Baltic Youth Core Groups Network project which is implemented within the South Baltic Program 2014-2020. The project's partnership is represented by entities from Denmark, Lithuania, Poland, and Sweden in which the quantitative research was carried out on civic participation of young people aged 14-24. The initial survey results have allowed confirming the hypothesis: the potential of the institutional environment of youth is not fully exploited in the process of increasing civic participation of young people in municipalities involved in the South Baltic Youth Core Groups Network Project. The research has revealed the strengths and weaknesses and barriers and opportunities of public institutions and non-government organizations to enhance youth civic participation in project partner countries.
\end{abstract}

KEYWORDS: youth, civic participation, project the South Baltic Youth Core Groups Network, SB YCGN project.

JEL: D700, H190, J240

\section{Introduction}

The idea of civic participation was born in the 1970s in Western Europe. It was a response to the search for mechanisms to effectively joint the functions of a democratic state with a market economy. The crisis of parliamentary democracy intensified the discourse on civic participation, within that the concepts of civil dialogue, social dialogue and the concept of participatory democracy were developed. Participatory democracy gives citizens the opportunity to express their opinions and present arguments in the process of making political decisions. This means governance on the basis of a social consensus regarding the most important political and socio-economic issues. It is achieved in the process of involving many various entities (public and non-public at different levels) and using diverse forms of influence on the shape of final decisions (Mandrysz, 2010: 27-29).

Izabela Borucińska - Ph.D in political science, Senior Lecturer at Department of Social Science and Philosophy, Faculty of Management and Economic, Gdańsk University of Technology, Poland

Scientific interests: civic participation, youth policy

E-mail: ibo@zie.pg.gda.pl 
Since the second half of the 20th century, the evolution of the public decision-making model could be observed. The traditional model based on limited access of organizations representing society to decisionmaking processes opens up as a result of inefficient solutions and global social, economic and technological changes. It is also connected with rising public awareness and increasing society's demands on more appropriate decisions of public authorities to cater to citizens' needs, and better-organized activity of social groups to defend their interests and articulate views on matters that concern them. As a consequence, the representatives of a democratic states' authorities must take into account their voice and their will to influence the decisions taken by public institutions. This has also resulted in making civic participation an element of modern management of the public sphere, in which decisions are taken collectively through dialogue, debate and negotiations. This allows for greater public acceptance and optimization of public decisions. In this way, civic participation has become a part of good governance because it enriches and complements existing democratic mechanisms with the tradition of deliberative democracy (Długosz, Wygnański, 2005: 11-12). The problem of civic participation is very complex and multidimensional (Teney, Hanquinet, 2012: 1213-1226), therefore it requires constant interdisciplinary research in changing circumstances.

The significance of young people in modern society results from two main reasons: human rights protection and their future role in society - those people will replace the currently ruling generation. Therefore, youth civic participation is a key aspect of the developing of any society in the future and should be shaped by effective youth policy (Rystina, Kussainova, 2014: 654-656). The first mentioned reason for working towards children's and young people's participation in decision-making results from the international law protection of human rights. The starting point is the UN Convention on the Rights of the Child with optional protocols and declarations like the Geneva Declaration of the Rights of the Child and the Declaration of the Rights of the Child. Regarding children and young adults also important are the other the UN conventions which prevent many different threats and protect their political, economic, social and cultural rights (United Nations). Those documents, among others, guarantee young people the rights to express their views freely in all matters affecting them, as well to take part in the government of their countries, directly or through freely chosen representatives in periodic and genuine elections based on universal and equal suffrage, and secret voting, as well to have an equal access to public service in their countries. In Europe, the protection of human rights (including children) is primarily dealt with the Council of Europe and the European Union, which based on the UN's regulations (See: Council of Europe; Organization for Security and Co-operation in Europe).

The children rights protection was introduced by the European Union into the Treaty on European Union. Its article 3 point 3 establishes the objective for the EU to promote "social exclusion and discrimination, and shall promote social justice and protection, equality between women and men, solidarity between generations and protection of the rights of the child" (Treaty on European Union). Also, the EU Charter of Fundamental Rights guarantees the protection of the rights of the child by the EU institutions and by its members through European law implementation. The provisions especially addressed to children rights protection are regulated by Article 24 and Article 31 on the prohibition of child labor ${ }^{2}$ (Applying the EU Charter of Fundamental Rights to children's rights in the EU. An assessment of the European Commission's 2014 Report on the Application of the EU Charter of Fundamental Rights and its contribution to protecting children's rights in the EU. Policy Paper 2015). The EU youth policy creates conditions to promote young people and implement their rights. It is regulated by the Treaty on the Functioning of the European Union. Article 165 of this treaty provides for the EU action in order to encourage the development of youth exchanges and exchanges between socio-educational instructors, i.e. youth workers. The Lisbon Treaty has made wider those provisions and included the EU activities to encourage the participation of young people in democratic life in Europe. Based on article 166, the EU can implement a vocational training policy to support and supplement the action of the Member States. It tasks the Union with facilitating access to vocational training and encouraging mobility of instructors and trainees, particularly young people. Moreover, children and young people

2 There are some problems with implementation the Charter provisions in all member states, it proofs a need to strengthen efforts in this area. See: European Union Agency for Fundamental Rights, Fundamental Rights Report 2018, http://fra.europa.eu/en/ publication/2018/fundamental-rights-report-2018. 
benefit from EU policies in other fields, such as education, training, and health, or in relation to the rights and protection of children and young people (Treaty on the Functioning of the European Union).

The European Union's youth policy has been developing more and more intensively and comprehensively on two levels of consensus: intergovernmental - debates between representatives of Member State governments and non-governmental - the social consultation process involving scientists, local and regional politicians, youth workers and youth. The youth problems were undertaking since the first programme in this area in 1989. The EU, through the different types of activities, has contributed cooperation development between youth work actors on the ground, and also created a framework for policymaking which would be a response to the young people needs. Also, those actions have supported an increasing young people citizenship and social solidarity competences through European Voluntary Service. The EU growing interest of young people could be more and more clearly observed since the consultations undertaken on preparing the White Paper on Youth (A New Impetus for European Youth. White Paper). This document presented key aspects of youth policymaking. The policy should face the problems those a significant number of young people have lost confidence in decision-making systems and disaffected in terms of traditional participation in public life and youth organizations, policymaking should be focused on the individuals and support their participation in society preventing the alienation process. The youth policymaking should be developed at the European level, as well as at its member states and regional levels. The White Paper also emphasizes the role of the Open Method of Coordination in the field of youth policymaking which allows the active participation of young people in direct dialogue and their involvement in policymaking initiatives.

Youth civic participation, as an important element of policymaking, has also become a part of the White Paper on Youth. Citizenship has a key role in shaping societal models premising on equity, participation and individual contribution to the welfare of community life at national state and regional level. It is also important at the European level, especially since the European citizenship was introduced by the Maastricht Treaty. Different aspects of youth civic participation development have supported and developed by many programs in the education, training and youth fields, including those connected with the Lisbon strategy and Europe 2020 strategy and the EU Youth Strategy covering the years 2010-2018 and the EU Youth Strategy for 2019-2027 presented by the European Commission in May 2018. The new EU strategy part named "Participation in civil society" aims encouraging young people to participate in the democratic process and in society. Its main objectives are: 1) to develop mechanisms to engaging in dialogue with young people and facilitate their participation in the shaping of national policies; 2) to support youth organizations, including local and national youth councils; 3) to promote participation of under-represented groups of young people in politics, youth organizations, and other civil society organizations and 4) to support ways of learning to participate from an early age (European Research on Youth Supporting young people to participate fully in society The contribution of European Research, 2009; Europe 2020. A European strategy for smart, sustainable and inclusive growth; EU Youth Strategy). All the EU documents and projects indicate that the capacity of the public institutions and NGOs could significantly influence increasing youth civic participation of young people. The base of it should be the partnership between adults and young people. It is the core of the policymaking process. Policy-makers should not operate in a surrounding of other policy-makers. Young people should be key stakeholders participating in public policies development and in decision-making processes. Policy-makers should take into account that their future actions towards youth should be strategic, well planned, flexible and targeting individuals or structures. And young people participation within the youth policy should be a core element of its development, implementation, and evaluation.

The aim of this paper is to determine the importance of the potential of public institutions and nongovernmental organizations in increasing civic participation of young people on the example of the South Baltic Youth Core Groups Network Project (SB YCGN) (SB YCGN, Interreg).

The research problem regards recognizing which elements of the potential of public institutions and nongovernmental organizations in shaping the civic participation of young people in the countries of the South Baltic are well developed or unexploited. The paper was focused on presenting the pilot surveys results of institution representatives which were conducted in Danish, Lithuanian, Polish and Swedish municipalities 
within the South Baltic Youth Core Groups Network Project on May 2018. Those results cannot be considered as representative for all countries of SB YCGN project and therefore shall be interpreted accordingly. They were mainly used to test the research tool. However, their effects can be also used to sketch out some strengths and weaknesses of the institutional environment of young people in shaping their civic participation at the local and cross-border level.

The following hypothesis was examined: the potential of the institutional environment of Youth has not fully exploited in the process of increasing civic participation of young people in municipalities involved in the South Baltic Youth Core Groups Network Project.

To reach this paper aim the scientific methods have been used such as literature review, comparable analyze and case study.

\section{Civic participation definition - makes a difference in public life}

There is no consensus on a single definition of civic participation, in part because it has been often mixed with civic engagement (see: Wing, 2009: 181-196; Zaff, Boyd, Li, Lerner, Lerner, 2010: 736-750). That term is used to determine citizens' participation in making and implementing decisions by public authorities and administrations. Generally, it means that people have the possibility to speak and participate in activities and decisions taken by public authorities that concern them as citizens.

Thus, civic participation is a process in which citizens influence the decisions of public authorities concerning them and indirectly are given control over them. It differs from traditional participation in the electoral process because civic participation enables citizens to influence the shape of decisions at an early stage of their formation. It also increases the likelihood of citizens' involvement in those decisions' implementation (Dugosz, Wygnański, 2005: 11-12, 22). Civic engagement means involvement "working to make a difference in the civic life of one's community and developing the combination of knowledge, skills, values and motivation to make that difference. It means promoting the quality of life in a community, through both political and non-political processes" (Ehrlich, 2000: 61). It includes paid and unpaid forms of political activism, environmentalism as well as community and national service (Michelsen, Zaff, Hair, 2002). In the literature can be found four interrelated components of civic engagement: 1) civic actions - participation in activities such as volunteering and service-learning (Bobek, Zaff, Li, Lerner, 2009: 615-627); 2) civic commitment or duty - willingness to make positive contributions to society; 3) civic skills - ability to be involved in a civil society, politics and democracy; 4) social cohesion understood as a sense of reciprocity, trust and bonding to others. Base on that, the main forms of civic engagement can be recognized: volunteering, national service, and service-learning. The evidence of that is observing a discourse intensification on youth civic engagement developing among scientists, politicians, non-government sector representatives, and other groups interested in. Therefore, there are available more and more scientific publications, national and international reports and different actions like conferences, seminars ect. The effectiveness of participation depends on the purpose and manner of communication between citizens and the authorities, the existing will of dialogue and co-decision on both sides and their preparation for joint action. Participation can take the following forms: a collectivistic form (anyone who can be affected by the consequences of a decision, should have equal access to the decision-making process) and an individualistic form (an individual person is able to participate and make decisions regarding the choice of social services for themselves); a holistic form (the decision-making method encourages people to think in terms of a common good); a particular way (decision-making method encourages people to think in terms of particular interests) (Dugosz, Wygnański, 2005: 13-14). Methods of civic participation are determined by different elements like the purpose and subject of the decision and the desired degree of citizens' influence on those decisions. Also important are the number of participants involved in the process and their role, type of decision's beneficiaries, scope and specifics of initiatives to involve citizens in the co-decision-making process, as well financial, material and timing resources available to their implementation. The basic form of expressing the influence of citizens on public life are the political elections of representatives to the authorities at the national, regional and local levels. However, not all 
social groups are able to enter their representatives into the authorities, which creates a sense of not taking into account their needs in the authorities' policies. In addition, in situations where the policy of elected authorities does not well meet with the social needs, citizens lose faith that they can have a real impact on public authorities' actions and finally citizens lose the confidence in their public representatives. A trend of declining participation of citizens in elections has been observing since the 1950s, in many countries in the world, including Western Europe (Dugosz, Wygnański, 2005: 7). This problem also applies to young people who do not fully exercise their electoral rights (active and passive). Many of them have no confidence in their involvement can change anything. They also become less and less interested in public affairs, and voting in political elections (Sloam, 2016: 521-537; Carlin, 2006: 632-651; Delli, 2000: 341-349; Kimberlee, 2002: 85-98; O’Toole, Lister, Marsh, Jones, McDonagh, 2003: 45-61; Phelps, 2005: 482-487; Skelton, Valentine, 2003: 117-134; Pacheco, 2008: 415-436; Wilkinson, Mulgan, 1995; Wiseman, 2006: 18-23; C Bromley et. al., 2004; Crozier, Huntington, Watanuki, 1975; Pharr, Putnam, 2000; Pharr, Putnam, Dalton, 2000: 5-25; Shields, 2006: 118-137; Youth, Political Participation and Decision-making). This does not mean the full resignation of young people from civic participation. While the voter turnout of young people decreases, other unconventional civic activities expand in different countries (Norris, 2002; Melo, Stockemer, 2014: 33-53). There are diverse methods of civic participation in decision-making processes. It can be distinguished among others: referendum, civic legislative initiative, request for public information, public consultations, public hearings, complaints, indirect representative bodies, contacts with a representative of public authorities, participation in the deliberations of the authorities, meetings with residents, civic panels, roundtables, petitions, demonstrations, protests, internet communication and interaction tools.

\section{Selected factors of youth civic participation}

Youth civic engagement depends on many factors which are highly connected with socialization process young people until 25 age. During that period young people are strongly affected by their families, neighborhood and schools or universities, as well as the peers' influence (Pancer, 2015: 21-126). The attitude and habits which are shaped by parents, teachers, colleagues and different groups or organizations may positively or negatively impact youth civic participation. In this phase of socialization adults play the most important role in the development of young people further and their civic adult behavior. Young people, who have experienced volunteer are more willing to engage in that type of civic participation and community activities or other forms of public life in adults period than their peers without a volunteering experience in the past. The similar effect, even stronger, can be achieved by youth involvement in after-school or non-universities activities or non-school or non-universities organizations (Andolina, Jenkins, Zukin, Keeter, 2003: 275280). The political and socio-economic environment in which young people live can have a serious impact on their ability to be engaged in civil society life. The factors such as low level of welfare, poor perspectives for stable employment and outdated or improper education systems limit young people possibilities to meet their needs in changing surroundings. It results in discourage youth to get involved in diverse forms of civic participation to solve their community life problems. Although many young people via their engagement in online and in the streets protests and demonstrations express their discontent due to government policy those forms should not be treated as a core of youth civic participation. There have to be developed much wider forms of their civic engagement, which should be base on a high civic awareness, willingness, and skills of young people to get involved in a community life (World Youth Report on Youth Civic Engagement, 2013, 2014, 2016; The World Youth Report on Youth Civic Engagement 2017).

The significance of an active role of young people within the civil society has become more and more visible since the turn of 20th and 21st centuries. Development of the well functioning civil society requires cooperation between young people and adults, as well as a partnering attitude towards decision-making processes of both sides. J. Youniss, S. Bales, V. Christmas-Best, M. Diversi, M. McLaughlin, and R. Silbereisen (2002: 121-148) through defining the civic competence and the main factors those affect youth civic engagement, they outlined the responsibilities of schools, government, the commercial sector, and community 
organizations. In this context, can be formulated the statement that adults who represent various types of public institutions and non-government organizations play a significant role in shaping youth civic participation. The political, social and economic changes which took place in the turn of 20th and 21st century had brought new challenges towards civic participation. Among the others, those changes have revealed the need for developing youth policy more focused on the civic engagement of young people. It plays a more and more important role in the development of the communities. After the end of the Cold War, the countries of the former Eastern bloc started the processes of political and economic transformation, including the creation of civil societies. Due to the different historical, cultural or political conditions of these countries, in comparison to countries with an established democracy, there are differentiated patterns of civic participation. P. Mirazchiyski, D. H. Caro and A. Sandoval-Hernández ${ }^{3}$ (2014: 1031-1055) revealed that established democracies like Denmark or Sweden show higher anticipated participation then new one such as Lithuania or Poland, while students from Poland have lower levels of expected future participation than Lithuania. In countries like Lithuania and Poland, the declared participation of young people in political elections in the future was lower than in Denmark or Sweden. However, in new democracies, the level of intention of future informal civic engagement was higher than in established democracies. Regarding statements of joining a political party and standing a political candidate, Lithuania and Poland have characterized a higher level of young people declarations than respondents in established democracies such as Denmark and Sweden. Those differences between established and new democracies suggest that each society has its own specific problems related to youth civic participation. Therefore, it requires in-depth research and seeking different methods towards rising youth civic participation.

\section{The SB YCGN project research on institutional capacity towards increasing youth civic participation at the local and cross-border level}

One the important the EU instrument on concerning young people, including their civic participation, are international projects.

Many projects addressing youth problems were completed, and many of them are still run within the Research Framework Programmes and Territorial Co-operation Programmes. Those projects provide the knowledge, solutions and spread good practices on civic youth participation across Europe. The South Baltic Youth Core Groups Network Project (SB YCGN) is an example of that type of the EU policy towards youth.

The SB YCGN Project is implemented within the South Baltic Program 2014-2020 - priority axis: 5 Increasing cooperation capacity of local actors in the South Baltic area for the blue and green growth and specific objective: 5 - Improve the cooperation capacity of local South Baltic area actors through participation in cross-border networks. The project partnership consists total 14 entities, including 8 Project Partners: Municipality of Køge (Denmark), Klaipeda University, Public Establishment Samogitia Community Foundation, Telsiai District Municipality Administration (Lithuania), LP - Association of Polish Communes of Euroregion Baltic, Gdańsk University of Technology, Civis Polonus Foundation (Poland) and Vimmerby municipality - Culture and Leisure department (Sweden) and 6 Associated Partners - Municipality of City of Elblag, Municipality of Gdynia, Municipality of Town of Iława, Municipality of Nowe Miasto Lubawskie,

\footnotetext{
The main issue of Mirazchiyski, Caro and Sandoval-Hernández paper is to reveal the relationship between the background variables and the outcomes in terms of civic participation, to evaluate the model fit across the new European democracies and their counterparts, not to show the different models of civic participation in the 22 European countries. Their research results can be used to scratch the background of this article's problem because their results correspond with the subject of the SB YCGN project's research. The resemblance relates to recognizing youth civic participation patterns in Denmark, Lithuania, Poland and Sweden - these are countries of the SB YCGN project partnership and main factors that that shape youth's civic participation and engagement such as: the family, school, peers, non-governmental organizations, religion and media, gender, By contrast, the key difference between them is that Mirazchiyski, Caro and Sandoval-Hernández research concern the future civic participation of the 8-year-olds, while the SB YCGN project focuses on defining the existing level of civic participation of young people aged 14-24, its existing barriers from an adult perspective and possible ways to increase youth participation in public life by strengthening cross-border cooperation networks, developing the competence of representatives entities of the institutional environment and modeling processes of youth civic participation.
} 
Town and Commune of Dzierzgoń (Poland), Municipality of Hässleholm - EU office Skåne Nordost (Sweden). Duration of the project is from January 1, 2018 to December 31, 2019.

The main aim of the SB YCGN Project is to increase cross-border cooperation resulting in building capacity of local actors working with youth and to increase the benefits of soft cross-border cooperation for solving common youth issues. The project objectives were defined as follows: enhancing cross-border cooperation of young people in partner countries; improving capacity and competencies of local governments and their representatives to engage in civil dialogue with youth, and disseminating the project results for the development of future plans to increase youth civic participation at local and cross-border level in the South Baltic Region. The planned activities within the 5 project work packages will bring the following main outputs: a scientific comparative survey, a knowledge-based youth design model processes, a new-quality Youth Core Group Network, publications, a youth portal, cross-border campaigns, video materials. The work package 3 of the SB YCGN Project has a research character. It includes quantitative and qualitative cross-border research on public institutions and non-governmental organizations as well as young people aged 14-24. Those research are designed and run by the team: prof. dr. hab. Krystyna Gomółka, dr Izabela Borucińska (Gdańsk University of Technology) and prof. dr Ligita Šimanskienė, prof. dr. Rimantas Stašys, prof. dr Rasa Viederytė, dr Jurgita Paužuolienė (Klaipėda University).

The project aim requires to reach the specific knowledge which will allow increasing youth civic participation by greater involvement of young people and representatives of local authorities, schools, non-governmental organizations, etc. in cooperation at the local and cross-border level (networks) and increasing the competences of all stakeholders. Therefore, in the first stage, it is necessary to recognize the institutional environment needs and barriers in increasing youth civic participation in project countries. In order to fulfill that step, the pilot research was carried out in May 2018. Its main aim was to identify the needs of public institutions and NGOs in the field of increasing civic participation of youth at the local and cross-border level. The specific objectives have concerned to determine:

- the current and desirable level of civic participation of young people and forms of their involvement in solving local and cross-border problems, as well as their engagement in decision-making processes;

- the effective forms and methods of involving young people by public institutions and NGOs into an active public life;

- the key barriers to increase the civic activity of young people and ways to overcome them from the institution's perspective;

- the competences of representatives of local public institutions and NGOs which require strengthening in the scope of increasing civic participation of young people.

The research population included people representing public institutions and non-governmental organizations who cooperate with young people aged 14-24 in partner communes (Dzierzgoń, Elbląg, Gdynia, Iława, Køge, Nowe Miasto Lubawskie, Telsiai, Vimmerby), as well as adults who are dealing with youth problems and acting to strengthen youth civic participation. The sample size accounted 48 respondents, including local politicians; officials of the City Hall; employees of city or commune offices and other institutions which are subordinated to the local government such as employees of a culture clubs, teachers and NGOs staff. The method was the non-probability sampling method - Judgement (Purposive) Sampling. The research was carried out as a diagnostic survey using the technique - direct survey. The paper questionnaire as the research tool contained mostly closed, rating questions, a few semi-open and open ones.

It should be noted, the results of the pilot research are unrepresentative and therefore they can not constitute a strong basis for formulating definitely conclusions about the whole research population. Those the pilot research are useful mainly to assess the correctness of the research tool. However, its results can be also carefully used to outline possible tendencies in the perception of different issues by respondents and to suggest unexploited areas of the potential of the institutional environment in increasing the youth civic participation. Only the final research on a representative sample, that will be carried out in 2019, will reveal a more complete picture of the problem. 
First of all, those research results have shown that the level of civic participation of young people in the local and cross-border dimension in project partner communes had not reached a satisfactory level. The most respondents $(56.25 \%)$ evaluated youth civic participation in their commune at a medium level, and $25 \%$ of respondents assessed it at a small level. If that scope of youth civic participation does not meet to local community needs than it will require more efforts to change that situation. Due to that an important project task is to identify the factors affecting youth civic engagement and areas those youth can influence through participation in the decision-making process. The research results revealed the mostly little impact of young people on different issues of which adults usually decide. Youth influences in very small or small extent on the following areas in the SB YCGN project municipalities respectively:

- $\quad$ spatial development (56.25\% of answers $/ 20.83 \%$ of answers);

- public transport (54.16\% of answers/22.91\% people of answers);

- preparation of strategic planning documents at the local level $(25.08 \%$ of answers $/ 22.91 \%$ of answers);

- allocation of local budget funds ( $45.83 \%$ of answers $/ 27.08 \%$ of answers);

- the election of representatives of Youth in the cross-border organizations ( $45.83 \%$ of answers $/ 27.08 \%$ of answers);

- education issues ( $41.66 \%$ of answers $/ 27.08 \%$ of answers);

- activities of political organizations ( $43.75 \%$ of answers $/ 29.16 \%$ of answers);

- international projects implemented in a commune (20.83\% of answers $/ 35.41 \%$ of answers). All above-presented opinions open the field to searching for reasons of such a state of affairs and its modifications.

There were identified different types of barriers in youth civic participation. The most respondents (66.66\% of people) said that their experiences in working with young people were unsuccessful because of a lack of mutual understanding and a lack of youth involvement in cooperation (33.33\% of people). Moreover, as the largest barrier in increasing youth civic participation the biggest number of people indicated a lack of faith among young people in their ability to influence local problems ( $25 \%$ of answers). Furthermore, most respondents have perceived following elements as a large limitation for youth civic engagement:

- young people's lack of interest in local life (45.83\% of answers);

- insufficient knowledge of politicians about youth problems (43.75\% of answers);

- a lack of faith among young people in their ability to influence local problems (41.66\% of answers);

- young people would like to decide on matters that they cannot have influence ( $37.5 \%$ of answers $)^{4}$;

- a lack of effective contacts between politicians and youth (35.41\% of answers);

- a lack of clear, understandable information about the opportunities for youth involvement in local matters, including their participation in the decision-making processes (33.33\% of answers);

- the adults do not allow young people to co-decide because youth ideas are inconsistent with the plans of an institution (31.25\% of answers).

Among a medium meaning barriers were predominated the following answers:

- a lack of long-term thinking about youth involvement in public affairs (41.66\% of answers);

- allow young people to give their opinion on decisions or not to take their opinions into account in the decision-making process; the parents or other caregivers of youth do not let them be involved in the decision-making process in local matters; a lack of effective forms in respondent's organization to motivate young people to get involved in local affairs (39.58\% for each answer);

- a lack of politicians interest in cooperation with young people and solving their problems; no financial resources in my organization for cooperation development with youth (37.5\% of answers);

- a lack of effective contacts between politicians and youth; no legal acts regarding youth participation in making decisions in an institution (33.33\% of answers);

- not allowing young people to co-decide because they have little knowledge and experience $(31.25 \%$ of answers).

\footnotetext{
This answer was indicated as a medium barrier by the same percentage of respondents.
} 
The presented barriers in shaping the participation of civic youth are on the side of both young people and the institutions themselves. In their overcoming the key role is played by adults as initiators, leaders, coaches and partners in cooperation for building an inclusive and welfare society. An important element of playing those roles is to define the needs of institutions in terms of increasing their ability to influence youth civic engagement, as well as effective methods, and tools that these institutions can use for this purpose. The most respondents $(56.25 \%)$ said that the most needed thing in their institutions is to find a good leader, who would be able to motivate and engage youth effectively ${ }^{5}$. In addition, $45.83 \%$ of respondents indicated some staff shortages, which stated that strengthening the capacity of their institutions would require employing a larger number of employees to work with youth.

According to the majority of respondents ( $47.91 \%$ of responses), there is also a very high need to increase young people participation in organizations representing their interests, such as the City or Commune Council, school or student self-government). Especially it regarding strengthening young people participation in formal social organizations at the local level (62.5\% of answers), in local government institutions (50\% of answers) and in informal educational organizations (42.75\% from answers) as well as in political youth organizations (33.33\% of answers). In the opinion of $42.75 \%$ respondents, the participation of young people in social activities of religious communities would be helpful in the development of their civic behaviors $^{6}$. The importance of organized forms of young people impacts on public life was also appreciated at an international level. $41.66 \%$ of respondents indicated the need for youth participation in cooperation with institutions implementing youth policy in the Baltic Sea Region. This is a confirmation of the significance of the transnational and cross-border projects such as SB YCGN.

Therefore, the question arises on what each institution can do to increase the civic engagement of young people. Respondents' answers can be divided into several areas: 1) awareness-raising and educational activities for the benefit of civic participation; 2) providing young people with the opportunity to give their opinion or postulates to local authorities, schools or universities or non-governmental organizations; 3) creating opportunities for giving opinions on draft decisions of the local government and school authorities and nongovernmental organizations by young people and 4) enabling young people to participate in the decisionmaking process by entities in the institutional environment. They correspond to the main elements of civic engagement such as knowledge, skills, values, motivation and available methods of influence to develop the public life of one's community through the political and non-political processes.

Regarding effectively developing the knowledge, skills, values and motivation the most respondents recognized primarily necessity of raising public awareness about the importance of youth participation in public life ( $41.66 \%$ of responses), including spreading the information in the mass media about examples of civic young people activities (56.25\% of responses) and about the possibilities of their involvement (37.5\% of responses), as well as the promotion of civic participation of young people in their youth environment (43.75\% of responses) and wider using social media and interactive videos for youth (50\% of responses). Relevant instruments would be also the meetings of officials with youth at schools (54.16\% of answers) and in public institutions, outside of the school (39.58\% of answers), as well as meetings of politicians with young people (54.16\% of answers). Furthermore, youth meetings with representatives of non-governmental organizations were recognized by $52.08 \%$ of respondents as an effective form of enhancement of young people's civic engagement. Those opinions have shown that adults who are institution's representatives play a very important role in creating and spreading the knowledge, skills and values for young people. They are able to motivate young people to be more involved in public life. However, adults also need specific knowledge and skills for resultful cooperation with youth. And the respondents have confirmed it $-47.91 \%$ of them said there exists a need to raise the competences of representatives of local government units, schools, and non-governmental organizations in the area of Youth involvement in public affairs. Respondents indicated it is a necessity of

Some difficulties in clear interpretation of this subject occurred because the answers were not fully compatible with the opinions on the barriers. Most respondents claimed that lack of a good youth leader is a small or very small problem in their organization (only $8.33 \%$ of respondents marked it as a very large problem and $16.66 \%$ of respondents as a large limitation).

6 However, it was unnecessary in the opinion of $25 \%$ of respondents and totally unnecessary of $12,5 \%$ of respondents. 
developing new knowledge or skills in the fields of psychology and pedagogy, especially regarding youth motivation to take action and sensitization youth on a local community needs. Motivation to be involved in shaping local public life and acting on including other people in that is not only a problem of youth. Adults also might have difficulties in that area.

Adults' motivation can be limited by previous, sometimes not very positive experiences in cooperation with young people. Also, the barriers can be adults' opinions such as young people want to decide on matters that they could not influence or an institution is just not interested in involving young people to solve local problems or young people cannot co-decide because their ideas are inconsistent with the plans of an institution or because they have too little knowledge and experience. For this reason, it is important to undertake various types of efforts to strengthen widely understanding the institution's capacity to develop civic participation of fashionable people. Useful ways to achieve that goal might be for example training of improving competences, the use of new and attractive forms of civic engagement for young people, participation in conferences and seminars as well as national and international projects related to this issue. The SB YCGN project partly responds to these needs because through organizing the workshops, group seminars, focus discussions for institutions' representatives and youth. All those actions contribute to the deepening of knowledge and dialogue, greater mutual understanding, overcoming barriers and the development of models of youth engagement in decision-making processes.

Educational and motivational activities for young people occasionally organized to get them involved in community life are not enough to develop their comprehensive civic participation. Adults need to create young people the sustain opportunities to speak on matters relating to them, to participate in consultations on local decisions and finally to participate in the decision-making process. The majority of respondents said that providing young people with the opportunity to present their opinions to public institutions and non-government organizations, including a giving formal opinion on their decisions, are effective methods of increasing the civic engagement of young people. In the opinion of $56.25 \%$ of respondents, youth should have an opportunity to give the opinions to non-governmental organizations. Young people's involvement in the activities of the non-governmental sector is of great importance for strengthening civil society, but equally valuable is their personal experience in terms of more direct influence on decisions of state institutions. In this matter, $45.83 \%$ of respondents said that youth should have an opportunity to present its opinions to school authorities and give an opinion on their draft decisions. A slightly smaller part of respondents $(33.33 \%)$ was of the opinion that this should also concern the draft decisions of local government. But in general matter, $50 \%$ of respondents defined that creating different opportunities for young people to present their opinions to local authorities is important. Despite those opinions, there could be recognized the limited propensity of the institutions' representatives to involve young people in decision-making processes. However, the $50 \%$ of respondents believe that providing young people with the opportunity to formally and organized present their opinions and to consult the decisions of local authorities through, for example, Youth Councils in municipalities would positively influence their civic participation. Also, young people's participation in public hearings organized by municipality officials and politicians was evaluated as an effective way by $47.91 \%$ of respondents, as well as organizing the "roundtables" as the form of a dialog between officials, politicians, and Youth was recognized as good tool increasing youth civic participation (39.58\% of answers). Creating young people the opportunities to present their opinions to a local government or a school or university authorities or a non-governmental organization is important for citizenship participation when those opinions are taken seriously into account by decision-makers. Otherwise, all parties lose their time and energy, and consequently also the motivation to the cooperation. This creates the illusion that young people influence anything, especially institutions' decisions. Therefore, the majority of respondents indicated that the implementation of postulates of young people by institutions is one of the effective ways to increase their civic participation. $58.33 \%$ of respondents believed that youth postulates should be implemented by local authorities, $54.16 \%$ of people said that by non-governmental organizations, and $47.91 \%$ of people claimed that school authorities must them into force. Those results show that adults are more supportive of giving young people opportunities to influence their decisions than direct involving youth to co-deciding process. 
Apart from the opportunities of speaking by young citizens on matters those concern them, a key issue is to allow them to participate in decision-making. It can be done through Youth Councils or other organized bodies. In connection with the adults' doubts concerning youth possibility to participate in decision-making on every public matter, the good solution would be the creation of a list of areas in which young people could co-decide. This idea was supported by the majority of $47.91 \%$ of respondents. One of the items on this list could be a participatory budget ${ }^{7}$, especially that $50 \%$ of the respondents were behind youth participation in co-deciding about part of commune's budget.

Among the other effective methods of increasing youth civic participation, $64.58 \%$ of respondents indicated the development of Youth cooperation in networks at the local level and $56.25 \%$ of them at the cross-border level. Therefore, the SB YCGN project idea of the development of the organized form of youth impact by creating the Youth Core Groups and by developing the cross-border network is a response for real need of enhancement youth civic participation in the South Baltic Region.

\section{Conclusions}

The research results have shown that the current level of civic participation of young people at the local and cross-border scope in project partner communes had not been at a satisfactory level. One of the reasons for it was inefficient cooperation between institutions representatives with young people in this area. The key role in increasing youth civic engagement play openness, will, activity, as well as the knowledge and skills of both parties and effective methods of cooperation. A comprehensive combination of those elements may contribute to multiplying the all stakeholders potential and consequently to developing and strengthening youth civic participation.

Due to the complex and multidimensional problem of civic participation, there exists a need of developing the constant and interdisciplinary research. This paper is an attempt to become a part in the discourse on that problem, but it requires in-depth exploration which will be carried out within the South Baltic Youth Core Groups Network Project and published in 2019.

Initial research, although based on not representative results, has allowed to sketch out some areas of the institutions' potential of young people environment in shaping their civic participation at local and crossborder level. The barriers which were tentatively identified by the institutions' representatives in increasing youth civic participation and its unsatisfactory scale in the analyzed municipalities have allowed outlining areas that institutions can use more effectively and those that need to be strengthened. The outlines of that problem were highlighted from the institutions' perspective and have indicated the existing unexploited their possibilities in the process of increasing civic participation of young people in municipalities involved in the South Baltic Youth Core Groups Network Project. Therefore, the hypothesis was confirmed.

The main elements of institutions' capacity towards enhancement youth civic participation are connected with their resources, tools and various possibilities to get wider involve young people in public life and decision-making processes. The material resources and human resources and tools such as law provisions or formal and informal methods of cooperation with young people should be more effectively used by institutions to stimulate youth civic participation. It is connected with using in practice the adults' knowledge and skills to make the changes in public life with youth participation, as well through their individual actions within civic participation process. However, the most powerful attribute of the adults is the possibility to make the decisions concerning young people and their potential participation in the decision-making process. Whether young people can be actively involved or not in shaping public life depends significantly on adults attitude to that problem. The institutions have greater opportunities to develop mechanisms to increase youth civic engagement than individuals or even groups of young people. This issue is directly associated with the pre-

\footnotetext{
A participatory budget is also referred to as a civic budget. It is a type of formalized social consultations regarding the spending funds from a local government budget for the selected projects by residents by way of voting. This is a separate pool of funds from the commune's budget which is allocated based on the commune inhabitants decision. There is not a huge problem to create a participatory budget for young people and allow them to make a decision on its. See: Strzelecki, 2018: 52-63; Wójcik, 2018: 89-97; Adamiczka, 2017: 100-115; Osssowski, 2017: 145-158.
} 
vious aspect. If adults as the institution's representatives are aware of existing barriers to civic engagement of young people, they could make the efforts to overcome them. If adults have a will they are able to develop the initiatives to encourage young people to get involved in public life and to lead them through intricacies of civic participation by training them how to influence on matters those concern them, as well by let young people participate in the decision-making process. Adults' open attitude to the cooperation with young people towards common shaping the reality requires determination and systematic efforts from them. Due to adults' role in discovering and opening the world of institutionalized public life to young people, adults' mindset, behavior, and actions may effectively be transferred to young people. Adults through their civic activeness and cooperation with young people can increase youth capacity to be aware and engaged citizens who feel a responsibility for building their community welfare. Adults can be more active in encouraging young people to be interested in public matters and to get involved in civil actions. Adults who represent the family environment, institutions such as schools, universities, local government, political parties or non-government organizations should be a source of knowledge and skills for young people, as well of civic participation patterns. They also suppose to play a role of leaders and trainers for youth in the fields of public problems, formal and informal ways of civic impact on decision-making processes. It is primarily adults who should aim for breaking institutional and their own barriers in shaping youth civic participation, as well looking for effective forms of youth involvement. Also, in this way, they might facilitate overcoming the barriers existing on the side of young people and cooperate with them for the common good, involve them in decisionmaking processes, shape civic engagement and, as a consequence, influence youth civic participation. The will of young people to influence the decisions those concern them is not a sufficient resource in this respect. Youth is characterized by a low level of interest in public affairs and insufficient knowledge and ability to influence decisions regarding public affairs. Thus, young people need adults' support in developing its capacity for civic participation. In otherwise, a lack of adults' engagement in young people development process may negatively impact on youth views and its civic activity. It is important especially due to quickly discouraging of young people in the face of the need to on one's own find ways to get involved, the barriers from adults side who do not listen to them or do not pay attention to youth opinions when making decisions. The lack of civic engagement experience or unsuccessful attempts in this field in young age may result in their limited civic participation in adults' age. Therefore, depending on adults' activity and the patterns spreading by them, the civic participation process could either result in shaping pro-active young citizens or passive ones.

Potential of the public institutions and NGOs can be more effectively used to creating youth civic participation by strengthening, among the others: 1) the knowledge and skills of the public institutions and non-government organizations employees in that field, including transfer of the good international practices; 2) the trust and understanding between adults and young people to be partners for each other; 3 ) the opportunities to listen young people and allow them to influence public affairs (creation for young people the opportunities to give an opinion and to consult some adults' decisions, implementing youth postulates by adults as it possible, allowing youth co-decide on the public problems); 4) the organized forms of cooperation with youth which are recognized as effective ways of youth civic impact and engagement (at local, regional, central and international level); 5) awareness-raising of the public institutions and non-government organizations employees, youth and a whole society on significance youth civic participation. Those elements should help exploit and develop the existing energy of young people and their willingness to actively work for the local community. According to $50 \%$ of respondents who represented various types of institutions, young people want to have an impact on matters concerning them and they expect adults to help them to solve their problems. In the opinion of $37.5 \%$ of respondents, young people get involved in public life because they want to solve the local problems. In addition, $54.16 \%$ of respondents think that young people are trying to learn how to decide. This lead to the conclusion that adults should play key roles in developing youth civic participation as their leaders, mentors, coaches, and partners. An existing potential can be used to create and develop skills and patterns of civic participation among young people mostly by adults' leadership and their engagement in cooperation with youth. However, that cooperation requires mutual trust and understanding 
which is a fundamental aspect of relationship credibility, as well as the awareness of the importance of youth civic engagement and effective forms of communication and civic activities implementation.

An effective process of increasing youth civic participation requires two types of approach from up to down and from down to up. From the one side, it means that the government and local authorities policy aim should be creating wide opportunities for the citizens to speak up on public matters and participate in activities and decisions taken by authorities, organizations, schools, etc. that concern them as citizens. From the other side, it means the grassroots efforts of individuals or groups of the citizens aiming to influence the public institutions and NGOs' decision-makers towards implementing common initiatives and co-decisionmaking process on relevant issues.

\section{Bibilography}

Adamiczka, H. (2017). Civic Budget as an Instrument for Meeting the Needs of the Citizens on the Example of Wrocław. Architektura Krajobrazu, No. 2, p. 100-115.

Andolina, M. W., Jenkins, K., Zukin, C., Keeter, S. (2003). Habits from Home, Lessons from School: Influences on Youth Civic Engagement. Political Science\&Politics, Vol. 36, Issue 2, p. 275-280.

A New Impetus for European Youth. (2001). White Paper, European Commission, COM 681.

Applying the EU Charter of Fundamental Rights to children's rights in the EU. An assessment of the European Commission's 2014 Report on the Application of the EU Charter of Fundamental Rights and its contribution to protecting children's rights in the EU. (2015). Policy Paper. https://www.eurochild.org/fileadmin/public/05_Library/Thematic_priorities/01_Childrens_Rights/Eurochild/Applying_the_EU_Charter_of_Fundamental_Rights_to_children_s_ rights_in_the_EU.pdf

Bobek, D., Zaff, J., Li, Y., Lerner, R. M. (2009). Cognitive, emotional, and behavioral components of civic action: Towards an integrated measure of civic engagement. Journal of Applied Developmental Psychology, No. 30, p. $615-627$.

Bromley, C., Curtice J., Seyd, B. (2004). Is Britain Facing a Crisis of Democracy? London: UCL Constitution Unit.

Carlin, R. E. (2006). The Decline of Citizen Participation in Electoral Politics in Post-authoritarian Chile. Democratization, No. 13, p. 632-651.

Council of Europe. https://www.coe.int/en/web/children

Crozier, M., Huntington, S. P., Watanuki, J. (1975). The Crisis of Democracy. Report on the Governability of Democracies to the Trilateral Commission. New York, NY: New York University Press.

Delli Carpini, M. X. (2000). Gen.com: Youth, Civic Engagement, and the New Information Environment. Journal Political Communication, Vol. 17, Issue 4, p. 341-349.

Długosz, D., Wygnański, J. J. (2005). Obywatele współdecyduja, Przewodnik po partycypacji społecznej. Warszawa: Stowarzyszenie na rzecz Forum Inicjatyw Pozarządowych.

Ehrlich, T. (2000). Civic Responsibility and Higher Education. New York: American Council on Education / Oryx Press.

European Research on Youth Supporting young people to participate fully in society. (2009). The contribution of European Research. European Commission. http://ec.europa.eu/research/social-sciences/pdf/policy_reviews/policyreview-youth_en.pdf

Europe 2020. A European strategy for smart, sustainable and inclusive growth. http://ec.europa.eu/eu2020/pdf/COMPLET\%20EN\%20BARROSO\%20\%20\%20007\%20-\%20Europe\%202020\%20-\%20EN\%20version.pdf

EU Youth Strategy. https://ec.europa.eu/youth/policy/youth-strategy_en

Kimberlee, R. (2002). Why don't British young people vote at General Elections? Journal of Youth Studies, No. 5, p. $85-98$.

Mandrysz, W. (2010). Dialog społeczny i dialog obywatelski w procesie kształtowania polityki regionalnej Województwa Śląskiego, In: K. Wódz, P. Kulas (ed.). Dialog, demokracja, społeczeństwo obywatelskie. Wyższa Szkoła Biznesu w Dąbrowie Górniczej.

Melo, D., Stockemer, D. (2014). Age and Political Participation in Germany, France and the U.K.: A Comparative Analysis. Comparative European Politics, No. 12, p. 33-53.

Michelsen, E., Zaff, J., Hair, E. C. (2002). Civic Engagement Programs and Youth Development: A Synthesis. Washington, DC: Child Trends. 
Mirazchiyski, P., Caro, D. H., Sandoval-Hernández, A. (2014).Youth Future Civic Participation in Europe: Differences between the East and the Rest, Journal Social Indicators Research, Vol. 115, Issue No. 3, p. 1031-1055.

Norris, P. (2002). Democratic Phoenix. Reinventing Political Activism. Cambridge: Cambridge University Press.

Organization for Security and Co-operation in Europe. https://www.osce.org/

Osssowski, S. (2017). A Civic Budget as a form of civil participation, or an institutional PR tool.

The Civic Budget in the City of Poznań. Przeglad Politologiczny, No 4, p. 145-158.

O’Toole, T., Lister, M., Marsh, D., Jones, S., McDonagh, A. (2003). Turning Out or Left Out? Participation and NonParticipation Among Young People. Contemporary Politics, No. 9, p. 45-61.

Pacheco, J. (2008). Political Socialization in Context: The Effect of Political Competition on Youth Voter Turnout. Political Behavior, No. 30, p. 415-436.

Pancer, S. M. (2015). The Psychology of Citizenship and Civic Engagement. Oxford University Press.

Pharr, S., Putnam, R. (eds.) (2000). Disaffected Democracies? What's troubling the trilateral countries? Princeton, NJ: Princeton University Press.

Pharr, S. J., Putnam, R. D., Dalton, R. J. (2000). A Quarter-Century of Declinig Confidence. Journal of Democracy, No. 11, p. 5-25.

Phelps, E. (2005). Young Voters at the 2005 British General Election. The Political Quarterly, No. 76 , p. $482-487$.

Rystina, I., Kussainova, Z. (2014). Comparative Analysis of National Youth Policy in Different Countries ProcediaSocial and Behavioral Sciences, No. 140, p. 654-656.

SB YCGN, Interreg, South Baltic. https://southbaltic.eu/-/sb-ycgn

Shields, J. G. (2006). Political Representation in France: A Crisis of Democracy? Parliamentary Affairs, Vol. 59, p. $118-137$.

Skelton, T., Valentine, G. (2003). Political participation, political action and political identities: Young D/deaf people's perspectives. Journal Space and Polity, No. 7, p. 117-134.

Sloam, J. (2016). Diversity and voice: The political participation of young people in the European Union. The British Journal of Politics and International Relations, Vol. 18, No. 3, p. 521-537.

Strzelecki, A. (2018). The Development of Participation Budget in the Civic Society of Kujawsko-Pomorskie Voivodship. Law and Administartion in Post-Soviet Europe, No. 1, p. 52-63.

Teney, C., Hanquinet, L. (2012). High Political Participation, High Social Capital? A relational analysis of youth social capital and political participation. Social Science Research, Vol. 41, No. 5, p. 1213-1226.

The World Youth Report on Youth Civic Engagement 2017. (2017). https://www.un.org/development/desa/capacitydevelopment/tools/tool/world-youth-report-on-youth-civic-engagement/

Treaty on European Union, OJ C 202. (2016).

Treaty on the Functioning of the European Union, OJ, C 202. (2016).

United Nations. http://www.un.org/en/sections/issues-depth/human-rights/

Wilkinson, H., Mulgan, G. (1995). Freedom's children. Demos Paper, No.17. London: Demos.

Wing, N. (2009). Transformation of students into active and participatory citizens: an exploratory study in Hong Kong. Educational Research for Policy and Practice, No. 8, p. 181-196.

Wiseman, N. (2006). Get out the vote-not: Increasing effort, declining turnout. Options Politiques, p. 18-23.

World Youth Report on Youth Civic Engagement, 2013, 2014, 2016. https://www.un-ilibrary.org/children-and-youth/ world-youth-report-2016 a4137e60-en

Wójcik, A. (2018), Civic Budget as a Potential Source of Financing of Real Estate. Barometr Regionalny, Vol. 16, No. 1, p. 89-97.

Youniss, J., Bales, S., Diversi, M., McLaughlin, M., Silbereisen, R. (2002). Youth Civic Engagement in the TwentyFirst Century. Research on Adolescence, Vol. 12, Issue 1, p. 121-148.

Youth. Political Participation and Decision-making. https://www.un.org/esa/socdev/documents/youth/fact-sheets/ youth-political-participation.pdf

Zaff, J., Boyd, M., Li, Y., Lerner, J. V., Lerner, R. M. (2010). Active and Engaged Citizenship: Multi-group and Longitudinal Factorial Analysis of an Integrated Construct of Civic Engagement. Journal of Youth and Adolescence, No. 39 , p. $736-750$. 


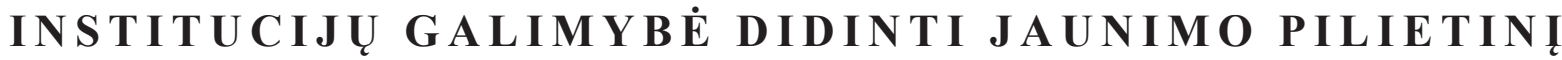 DALYVAVIMĄ - PIETŲ BALTIJOS JAUNIMO TINKLO PR O J E K TO T Y R I MAS}

IZABELA BORUCIŃSKA

Gdansko technologijos universitetas (Lenkija)

Santrauka

Jauni žmonės yra svarbi šiuolaikinės visuomenès grupè, juk būtent jie pakeis šiuo metu valdančią kartą ir kurs bendrą mūsų ateitị. Todèl jaunimas tapo svarbiu šalies ir tarptautinės politikos bei mokslo tyrimų tikslu. Jaunimo pilietinis dalyvavimas yra pagrindinis visuomenès vystymosi aspektas, jį turètų skatinti veiksminga jaunimo politika nacionaliniu ir tarptautiniu lygmenimis. Europos Sajungos jaunimo politikos gaires - tai dokumentas, kuriuo remiantis siekiama skatinti viešųų institucijų ir nevyriausybinių organizacijų bendradarbiavimą bei jaunimo pilietinị dalyvavimą Europos Sajungos jaunimo politikos kontekste. Tai atskleidžia ịvairių institucijų bendradarbiavimo svarbą skatinant jaunimo pilietinį dalyvavimą Pietų Baltijos jaunimo pagrindinių grupių tinklo projekto, kuris igyvendinamas pagal 2014-2020 m. Pietų Baltijos programą, pavyzdžiu. Vykdant projektą dalyvauja Danijos, Lietuvos, Lenkijos ir Švedijos organizacijos, kuriose atliktas 14-24 metų amžiaus jaunimo pilietinio dalyvavimo kiekybinis tyrimas. Pirminiai tyrimo rezultatai patvirtino hipotezę: jaunimo institucinès aplinkos potencialas išnaudojamas ne visapusiškai didinant jaunimo dalyvavimą savivaldybẻse, kurios dalyvauja vykdant Pietų Baltijos jaunimo pagrindinių grupių tinklo projektą.

Tyrimas atskleidẻ viešųų institucijų ir nevyriausybinių organizacijų stipriąsias ir silpnąsias puses, kliūtis ir galimybes didinti jaunimo pilietinį dalyvavimą projekto partnerių šalyse. $50 \%$ respondentų, atstovavusių ịvairių tipų institucijoms, teigimu, jaunimas nori daryti ịtaką sprendžiant jiems aktualius klausimus ir tikisi, kad suaugusieji padès jiems išspręsti jaunimui aktualias problemas. 37,5 proc. respondentų mano, kad jauni žmonès ịsitraukia ị viešaji gyvenimą, nes nori spręsti vietines problemas. Be to, 54,16 proc. respondentų mano, kad jauni žmonès mokosi priimti sprendimus tiek mokydamiesi mokykloje, tiek dalyvaudami visuomenineje veikloje. Taigi suaugusieji turètų skatinti jaunimo pilietinį dalyvavimą ir veikti kaip lyderiai, mentoriai, partneriai.

Kad jaunimo pilietinis dalyvavimas būtų veiksmingas, institucijos turi susikalbèti vietos ir regioniniu lygmenimis. Viena vertus, tai reiškia, kad vyriausybe ir vietos valdžios institucijos turètų siekti sudaryti galimybę piliečiams kalbèti viešaisiais klausimais ir dalyvauti veikloje bei valdžios institucijoms, organizacijoms, mokykloms ir kitoms institucijoms priimant sprendimus. Kita vertus, tai rodo piliečių ar jų grupių pastangas paveikti viešąsias institucijas ir NVO sprendimus priimančius asmenis, igyvendinant bendras iniciatyvas ir kartu priimant sprendimus rūpimais klausimais.

PAGRINDINIAI ŽODŽIAI: jaunimas, pilietinis dalyvavimas, Pietu Baltijos jaunimo pagrindiniu grupiu tinklo projektas, SB YCGN projektas.

JEL KLASIFIKACIJA: D700, H190, J240

Received: 2019.02.10

Revised: 2019.03.23

Accepted: 2019.04.28 